\title{
Budżet partycypacyjny \\ - rzeczywisty czy pozorny instrument partycypacji społecznej. Przykład Łodzi
}

\author{
Magdalena Kalisiak-Mędelska \\ Dr, Uniwersytet Łódzki, \\ Wydział Ekonomiczno-Socjologiczny \\ Zakład Logistyki \\ http://dx.doi.org/10.18778/8088-114-3.21
}

\section{Wprowadzenie}

Reformy ustrojowe, jakie miały miejsce w Polsce na początku lat 90., w tym reaktywacja samorządu terytorialnego, stworzyły ramy dla uruchomienia demokratycznego mechanizmu dobrowolnego udziału obywateli w zarządzaniu właściwymi im sprawami publicznymi. U podstaw tego prawa uczestnictwa leży przekonanie, że obywatele najlepiej się orientują we własnych potrzebach dając temu wyraz poprzez różnego rodzaju działania podejmowane w celu wpłynięcia na ostateczny kształt decyzji władz publicznych. Partycypacja społeczna daje zatem obywatelom możliwość oddziaływania na bezpośrednie otoczenie poprzez szereg form począwszy od artykulacji swoich opinii i poglądów do realnego współrządzenia. Jednym z przejawów realnej aktywności obywatelskiej jest uczestnictwo $\mathrm{w}$ procesach decyzyjnych $\mathrm{w}$ obszarze kształtowania struktury wydatków w ramach wyodrębnionej części budżetu tzw. budżetu partycypacyjnego ${ }^{1}$.

Pierwszy raz budżet partycypacyjny wykorzystano w Porto Alegre (Brazylia), jako przejaw zmiany sposobu myślenia o redystrybucji publicznych zasobów finansowych na poziomie miasta, regionu. Podłożem zainicjowanych reform było nawarstwianie się i utrwalanie wielu problemów społecznych i ekonomicznych (przestępczość, bieda, rozwarstwienie społeczne itp.). Wprowadzenie tego rodzaju budżetu miało więc na celu po pierwsze: włączenie wykluczonych grup społecznych $\mathrm{w}$ proces zarządzania sprawami

1 W Polsce bardzo często używa się określenia budżet obywatelski. W części empirycznej odnoszącej się do doświadczeń Łodzi z tego rodzajem budżetu stosowane będzie sformułowanie przyjęte przez władze Łodzi budżet obywatelski. 
publicznymi, tym samym zwiększenie ich współodpowiedzialności za szereg właściwych im spraw publicznych, po drugie: poprawę przejrzystości i efektywności wydatkowania środków publicznych, po trzecie: budowanie wzajemnego zaufania pomiędzy władzami i mieszkańcami ${ }^{2}$ Stał się on wielkim sukcesem, przede wszystkim ze względu na fakt, że mieszkańcy uzyskali prawo bezpośredniego decydowania (a nie zatwierdzania propozycji), w jaki sposób środki finansowe mają być rozdysponowane oraz projektowania, a następnie sprawowania pełnej kontroli nad jego realizacją ${ }^{3}$. To spowodowało, że zyskał on ogromną popularność w Europie, Afryce, Azji, Ameryce Północnej, już nie tylko jako narzędzie przemian w zakresie wydatkowania środków publicznych, ale także do rozwiązywania określonych problemów konkretnych grup społecznych np. seniorów, młodzieży szkolnej4

Instytucja budżetu partycypacyjnego, wraz z umacnianiem się i rozwojem partycypacji społecznej, stała się więc coraz powszechniejsza zdobywając rzesze zwolenników jak i przeciwników. Tym samym pojawia się wątpliwość, na ile jest on rzeczywistym instrumentem partycypacyjnego zarządzania, a na ile jedynie przejawem politycznej mody czy też chęci odniesienia politycznych korzyści.

Artykuł koncentruje się na budżecie partycypacyjnym, jako wyrazie woli obywateli odnośnie przeznaczenia określonych kwot środków finansowych będących w dyspozycji władz lokalnych. W związku $\mathrm{z}$ tym analizie poddano trzy edycje budżetu obywatelskiego w Łodzi tj. 2014, 2015 i $2016^{5}$ pod kątem doświadczeń i praktyk. Nie chodzi jednak o ocenę poprawności zastosowania budżetu, a jego rzeczywiste przełożenie na decyzje obywateli w ważnych sprawach związanych z dobrem wspólnym. Stąd też uwagę skoncentrowano przede wszystkim na ogólnych warunkach wdrażania budżetu obywatelskiego w Łodzi w kontekście wielkości samego budżetu i zadań w nim ujętych. Takie podejście stanowi punkt wyjścia do dyskusji na temat określenia jego znaczenia, jako instrumentu poszerzania i wzmacniania zainteresowania oraz udziału wszystkich mieszkańców w sprawach ich wspólnego miasta (partycypacja społeczna). Pozwoli ono również na próbę oceny efektywności wydatkowania w ten sposób środków finansowych.

2 P. Sadura, Podzielmy się kulturq. Budżet partycypacyjny w Domu Kultury Śródmieście. Opis procesu wraz z rekomendacjami, Warszawa 2013, s. 11.

3 G. Baiocchi, Participation, Activism, and Politics: The Porto Alegre Experiment, [w:] Depending Democracy. Institutional Innovations in Empowered Participatory Governance, red. A. Fung, E. O. Wright, London 2003, s. 48.

4 M. Szaranowicz-Kusz, Budżet partycypacyjny. Jak mieszkańcy moga współdecydować o budżecie miasta, Warszawa 2014, s. 6.

5 Analiza tej edycji budżetu obywatelskiego będzie ograniczona ze względu na przyjęty harmonogram realizacji poszczególnych jego etapów. Do 4 września 2015 r. ogłoszone zostaną listy zawierające propozycję zadań, na które można zagłosować, głosowanie przewidziane jest w dniach 19-27 września 2015 r., a ustalenie wyników głosowania przewidziano do 19 października $2015 \mathrm{r}$. 
Rozważania w części teoretycznej oparto na wybranych pozycjach literatury przedmiotu prezentujących ogólne zagadnienia związane zarówno z pojęciem i istotą partycypacji społecznej jak i budżetu partycypacyjnego, w części empirycznej zaś na materiałach Urzędu Miasta Łodzi odnoszących się do przedmiotowego zakresu opracowania.

\section{Budżet partycypacyjny jako przejaw partycypacji społecznej}

Przejawem chęci aktywnego włączenia się obywateli w proces stanowienia prawa i realizacji polityk publicznych jest partycypacja społeczna. Wyraża ona nowy wymiar zarządzania sprawami publicznymi, uwypuklający inne niż dotychczas stosowane standardy, a mianowicie te które pozwalają obywatelom artykułować swoje potrzeby, bronić interesów, mediować w sprawach spornych, a co najważniejsze podejmować kluczowe decyzje ${ }^{6}$. Władzom natomiast tworzyć efektywne systemy zaspokajania potrzeb publicznych, platformę akceptacji społecznej i zaufania. Jej istotą jest, co należy bardzo mocno podkreślić, dobrowolne i świadome zaangażowanie obywateli w sprawy dla nich istotne. Uzyskują oni, obok opiniowania i wyrażania swoich preferencji, także możliwość wpływania na ostateczny kształt decyzji publicznych oraz kontroli ich realizacji ${ }^{7}$. Partycypacja społeczna oddaje więc rzeczywisty obraz społecznego odbioru zamierzeń władzy publicznej oraz przyczynia się do zwiększenia akceptacji społecznej przedsięwzięć publicznych. Kładzie nacisk na te elementy, które stają się coraz bardziej pożądane w obecnym życiu publicznym tj. transparentność, uczciwość i odpowiedzialność w rządzeniu, zaufanie, przywództwo, partnerstwo, konsensus czy solidarność z obywatelem ${ }^{8}$.

Trzeba mieć jednak świadomość, że partycypacja społeczna dotyczy najczęściej konkretnych grup interesu, tych których dany problem dotyka w sposób bezpośredni (np. zamieszkujących w pobliżu kontrowersyjnych inwestycji, chcących przeforsować swoje rozwiązania). Charakteryzuje się

6 E. Wojciechowski, A. Podgórniak-Krzykacz, M. Kalisiak-Mędelska, J. Chądzyński, Władza lokalna a państwo, społeczeństwo i rynek. Współpraca i konkurencja, Łódź 2014, s. 24.

7 Koncepcja Good Governance. Refleksje do dyskusji, Ministerstwo Rozwoju Regionalnego, Warszawa 2008, s. 8.

8 M. Kalisiak-Mędelska, Partycypacja społeczna - przymus czy rzeczywista potrzeba?, „Prace Naukowe Uniwersytetu Ekonomicznego we Wrocławiu” 2011, Nr 241, s. 264 (262-276). 
ona zatem selektywnym uczestnictwem, nie obejmuje wszystkich obywateli ${ }^{9}$. Część z nich jest z niej wyłączona, najczęściej z powodu braku zainteresowania sprawami swojej wspólnoty, małej gotowości do współdziałania i wspólnego rozwiązywania problemów czy też świadomości i wiedzy na temat swoich praw i możliwości wpływu na kształt polityk publicznych.

Partycypacja społeczna przejawia się szeregiem niewymuszonych, inspirowanych dobrem wspólnym, form aktywności obywatelskiej, zarówno tych związanych $\mathrm{z}$ demokracją bezpośrednią (np. referendum, wybory), jak i tych wypracowanych w odpowiedzi na potrzeby uczestników procesu partycypacji - bezpośrednie spotkania, panele obywatelskie, sondaże opinii publicznej (wykorzystywane są także takie narzędzia wyrazu woli obywateli jak np. pikiety, strajki, okupacje instytucji publicznych, nie urzeczywistniają one jednak partycypacji w znaczeniu, będącym przedmiotem niniejszych rozważań). Angażują one w różnym stopniu partycypantów. Inny efekt przyniesie bowiem sztywny, pozorny rytuał uczestnictwa, inny zaś rzeczywiste przedsięwzięcia generujące konkretne zmiany ${ }^{10}$.

Znamiennym przykładem rozwiązań ukierunkowanych na wsparcie rzeczywistej aktywności i kreatywności obywatelskiej (oczekiwanej partycypacji społecznej) jest budżet partycypacyjny (uważany za jeden z bardziej udanych instrumentów partycypacji ostatnich 30 lat). Jest on demokratyczną procedurą współuczestnictwa obywateli w tworzeniu polityki finansowej w zakresie realizacji wybranych projektów i inwestycji, głównie na poziomie lokalnym, gdzie namacalność podjętych przez nich decyzji jest znacznie większa niż na innych szczeblach. Uspołecznia on proces budżetowania w obszarze określonej hierarchii celów określonych przez samych obywateli. Nie jest to jednak sztywna delegacja uprawnień, a szczególny sposób podejścia do myślenia o partycypacyjnym zarządzaniu sprawami publicznymi. Jego idea mocno wpisuje się w koncepcję społeczeństwa obywatelskiego oraz governance, przy czym nie ogranicza się jedynie do bezpośredniego wpływu obywateli na kierunki zagospodarowania środków publicznych, ale zakłada ich zaangażowanie na wszystkich etapach procedury budżetowej ${ }^{11}$.

Kwestia definicji budżetu partycypacyjnego jest tematem bardzo obszernym, jest on bowiem wielorako interpretowany. Pojęcie to odnoszone jest czasami do konsultowania przedkładanych przez władze publiczne propozycji lub też obrazuje wybór tych wskazanych przez obywateli w postępowaniu

9 E. Turnhout, S. Van Bommel, N. Aarts, How Participation Creates Citizens: Participatory Governance as Performative Practice, „Ecology and Society” 2010, No. 15(4):26, http://www.ecologyandsociety.org/vol15/iss4/art26/ (dostęp 10.03.2014).

10 M. Kalisiak-Mędelska, Partycypacja społeczna na poziomie lokalnym jako wymiar decentralizacji administracji publicznej w Polsce, Łódź 2015.

11 A. Rytel-Warzocha, Partycypacja społeczna w sprawach budżetowych. Model Porto Alegre jako pierwowzór rozwiqzzań europejskich, „Przegląd Prawa Konstytucyjnego" 2010, Nr 1, s. 94. 
konkursowym. Można się również spotkać z bardzo szerokim podejściem wskazującym na prawo mieszkańców do wpływu na całokształt i złożoność miasta ${ }^{12}$. Nie można ich jednak traktować w kategorii partycypacji obywateli w tworzeniu i realizacji budżetu ${ }^{13}$. Uogólniając, budżet obywatelski jest niczym innym jak demokratycznym procesem dyskusji i podejmowania decyzji odnoście przeznaczenia środków publicznych z udziałem obywateli (mieszkańców). W tym ujęciu można go traktować jako rozdysponowanie przez mieszkańców przekazanych na ich rzecz wydzielonych środków publicznych. Wydaje się, iż takie podejście spłyca istotę omawianego budżetu, który powinien zakładać bezpośredni udział mieszkańców w planowaniu i kontrolowaniu wydatkowania środków publicznych (tabela 1).

\begin{tabular}{|l|l|}
\hline $\begin{array}{l}\text { K. Marchewka- } \\
\text {-Bartkowiak }\end{array}$ & $\begin{array}{l}\text { Wydzielona część budżetu np. gminy, w ramach którego wyznaczona odgór- } \\
\text { nie kwota wydatków przeznaczona jest na inicjatywy i projekty inwestycyjne } \\
\text { bezpośrednio zgłaszane przez członków danej wspólnoty (indywidualnie lub } \\
\text { przez właściwe organizacje) }\end{array}$ \\
\hline A. Rytel & $\begin{array}{l}\text { Mechanizm bezpośredniego zaangażowania mieszkańców w cały cykl rzeczy- } \\
\text { wistego budżetowania tj. od przygotowania projektu uchwały budżetowej, } \\
\text { po monitoring i kontrole jego realizacji, zapewniający przejrzyste i odpowie- } \\
\text { dzialne zarządzanie wydatkowaniem środków publicznych będących w gestii } \\
\text { władz lokalnych }\end{array}$ \\
\hline W. Kłębowski & $\begin{array}{l}\text { Proces decyzyjny, w ramach którego mieszkańcy współtworzą budżet danej jed- } \\
\text { nostki, tym samym decydując o dystrybucji określonej puli środków pieniężnych }\end{array}$ \\
\hline B. Wampler & $\begin{array}{l}\text { Proces, poprzez który obywatele przedstawiają swoje żądania i priorytety } \\
\text { obywatelskie oraz wpływają na strukturę wydatków budżetowych poprzez } \\
\text { dyskusję i negocjacje }\end{array}$ \\
\hline $\begin{array}{l}\text { Y. Sintomer, } \\
\text { C. Herzberg, } \\
\text { A. Röcke }\end{array}$ & $\begin{array}{l}\text { Instrument uczestnictwa obywateli w procesie decydowania o środkach } \\
\text { publicznych. Prawo podejmowania decyzji przysługujące mieszkańcom } \\
\text { (wspólnocie), a nie jedynie grupie wyłonionej w drodze wyborów }\end{array}$ \\
\hline $\begin{array}{l}\text { C. Harkins, } \\
\text { J. Egan }\end{array}$ & $\begin{array}{l}\text { Włączenie mieszkańców w dyskusję i głosowanie w sprawie priorytetów wy- } \\
\text { datkowania środków publicznych, a także w kontrolę i monitoring przebiegu } \\
\text { procesu realizacji budżetu }\end{array}$ \\
\hline
\end{tabular}

Tabela 1. Wybrane definicje budżetu partycypacyjnego

Źródło: opracowanie własne na podstawie: Y. Sintomer, C. Herzberg, A. Röcke, Participatory Budgeting in Europe: Potentials and Challenges, „International Journal of Urban and Regional

Research" 2008, Vol. 32, s. 168 (164-178); A. Rytel-Warzocha, Budżet obywatelski jako nowa forma społecznej partycypacji, „Przegląd Naukowy Disputatio” 2013, Tom XV, s. 67; W. Kłebowski, Budżet partycypacyjny. Krótka historia obsługi, Warszawa 2013, s. 8; B. Wampler, A Guide to

Participatory Budgeting, [w:] Participatory Budgeting, The World Bank, Public Sector Governance and Accountability Series, s. 21; C. Harkins, J. Egan, The Role of Participatory Budgeting in Promoting Localism and Mobilising Community Assets, Glasgow 2012, s. 4.

12 Jest to podejście prezentowane przez amerykańskiego urbanistę P. Marcuse’a. Za: P. Głogowski, Poznański budżet obywatelski - analiza i rekomendacje, „Raport Stowarzyszenia Ulepsz Poznań" 2014, Nr 1, s. 5.

13 A. Rytel-Warzocha, Budżet obywatelski jako nowa forma społecznej partycypacji, „Przegląd Naukowy Disputatio” 2013, Tom XV, s. 68. 
Jak wspomniano wcześniej, budżet partycypacyjny narodził się w Ameryce Południowej w Brazylii i jako koncepcja został zaadaptowany przez wiele miast na całym świecie. Partycypacja obywateli w budżetowaniu nie ma jednak charakteru jednolitego ${ }^{14}$. Jego realizacja przebiega więc w zależności od zastanych uwarunkowań prawnych, społecznych, gospodarczych danej społeczności (aktualnie funkcjonuje kilka modeli budżetu partycypacyjnego, wśród których najbardziej znany i najczęściej stosowany jest model oparty na doświadczeniach Porto Alegre ${ }^{15}$ ). Różne są również funkcje, jakie ta forma zaangażowania obywatelskiego spełnia $\mathrm{w}$ procesie sprawowania władzy.

Konstrukcja budżetu partycypacyjnego jako takiego powinna jednak uwzględniać kilka kluczowych zasad, które odróżniają go od innych praktyk angażujących mieszkańców w bieg spraw publicznych ${ }^{16}$. Zasad, które determinują autentyczne współdecydowanie obywateli o kształcie polityk publicznych. Podstawową jest zasada współdecydowania. Budżet obywatelski nie jest wyrazem konsultowania przyjętych przez władze rozwiązań w obszarze wydatkowania środków finansowych (nawet jeśli dochodzi do zmiany ostatecznych decyzji pod wpływem opinii mieszkańców). Wyraża on przekazanie części decyzyjności samym mieszkańcom, a jego integralną częścią jest dialog publiczny. Decyzje powinny być poprzedzone debatą na temat $\mathrm{z}$ jednej strony propozycji przeznaczenia określonych środków wskazywanych przez mieszkańców, z drugiej zaś stanowiska władz dotyczącego najpilniejszych potrzeb w skali całego miasta. Stąd też realizacja budżetu partycypacyjnego musi odbywać się

14 A. Rytel-Warzocha, Partycypacja społeczna w sprawach budżetowych. Model Porto Alegre jako pierwowzór rozwiqzzań europejskich, „Przegląd Prawa Konstytucyjnego" 2010, $\mathrm{Nr}$ 1, s. 96.

15 Y. Sintomer, C. Herzberg, A. Röcke wyróżnili między innymi sześć modeli budżetu obywatelskiego, a mianowicie model: (1) Porto Alegre dostosowany do warunków Europy, (2) uczestnictwa zorganizowanych grup interesu, (3) negocjacji publiczno-prywatnych, (4) konsultacji, (5) bezpośredniego udziału (bezpośrednie głosowanie), (6) wydzielonych funduszy na szczeblu miasta Wyróżnienie wymienionych modeli oparto na następujących kryteriach: źródło pochodzenia środków finansowych rozdzielanych wedle procedury budżetu partycypacyjnego, sposób i stopień uczestnictwa mieszkańców w procesie podejmowania decyzji (organizacji spotkań np. zespoły tematyczne, zamknięte, otwarte publiczne spotkania), sposób przeprowadzania dyskusji (dyskusja, konsultacje, zakres uczestnictwa obywateli w procesie). Y. Sintomer, C. Herzberg, A. Röcke, Participatory Budgeting in Europe: Potentials and Challenges, „International Journal of Urban and Regional Research” 2008, Vol. 32, s. 169.

16 Zob. M. Szaranowicz-Kusz, op. cit., s. 9-10, Participatory Budgeting in New York City. 2012-2013 Rulebook, www.participatorybudgeting.org/wp-content/uploads/2012/07/Rulebook.pdf (12.06.2015); Y. Sintomer, C. Herzberg, A. Rocke, G. Allegretti, Transnational Models of Citizen Participation: The Case of Participatory Budgeting, „Journal of Public Deliberation” 2012, Vol. 8: Iss. 2, s. 2-3. 
w oparciu o jasne, czytelne, zrozumiałe i spisane reguły, znane wszystkim jego uczestnikom (zasada przejrzystości i jawności procedury). Zachowanie powyższych zasad jest niezwykle ważne z punktu widzenia aktywizacji tych grup mieszkańców, które pozostają poza nurtem partycypacyjnego uczestnictwa w życiu wspólnoty (np. rozczarowanych kształtem realizowanej przez władze polityki). Wymaga to obopólnego zaufania będącego podstawą dalszej współpracy władz z mieszkańcami, przede wszystkim jednak otwartości władz na potrzeby całej społeczności, a nie jedynie wybranych grup interesu.

Bezpośrednio z zasadą współdecydowania koresponduje zasada przyjęcia wiążącego charakteru decyzji podjętych przez mieszkańców oraz równości dająca wszystkim obywatelom możliwość przedłożenia propozycji wydatkowania wskazanych środków i późniejszego nad nimi głosowania. Należy tutaj zaznaczyć, iż prawo decydowania dotyczy jasno określonych i ograniczonych środków finansowych. Uczestnicy budżetu partycypacyjnego powinni znać dokładną kwotę pozostającą w ich dyspozycji (ta cecha jest niejednokrotnie nazywana przez oponentów jako „koncert życzeń mieszkańców” w obrębie niewielkich środków finansowych). Budżet partycypacyjny nie powinien być jednak ograniczony do małych wyodrębnionych obszarów np. dzielnicy, osiedla, instytucji. W swoim założeniu wskazane jest, by obejmował również w jakiejś części projekty służące ogółowi mieszkańców. Zmniejsza to ryzyko dominacji partykularnych interesów pojedynczych grup społecznych czy nawet opcji politycznych.

Aby mówić realnie o budżecie partycypacyjnym, trzeba mieć świadomość trwałego włączenia go w proces zarządzania publicznego. Efekty jego zastosowania są widoczne dopiero $\mathrm{w}$ dłuższej perspektywie czasowej, nie może być on więc incydentalnym przedsięwzięciem, a długofalowym, cyklicznie organizowanym.

Zaprezentowane wytyczne nie stanowią zamkniętego katalogu. Procedura budżetu partycypacyjnego powinna zapewnić rzeczywistą władzę decyzyjną mieszkańcom i być podstawą współpracy z władzami oraz jednym z etapów budowania silnego społeczeństwa obywatelskiego. Sam budżet partycypacyjny niesie za sobą szereg ogólnych korzyści w postaci wzmocnienia procesu decentralizacji władzy publicznej, demokratyzacji procesu decyzyjnego, urzeczywistnienia zasady równości i sprawiedliwości społecznej oraz zwiększenia przejrzystości zarządzania, w tym środkami publicznymi. Prezentowany rodzaj budżetu nie jest jednak pozbawiony słabych stron. Wynikają one $\mathrm{w}$ głównej mierze $\mathrm{z}$ wadliwości procedury (nierealistyczny harmonogram, zbyt krótki czas na przygotowanie przez mieszkańców projektów, niewłaściwa procedura weryfikacji zgłoszonych projektów itp.), braku wiedzy i doświadczenia w tym zakresie, zarówno po stronie władz jak i samych mieszkańców (brak konsultacji 
społecznych w sprawie procedury budżetu partycypacyjnego, wykorzystanie niewłaściwych kanałów przekazu informacji, ograniczona akcja promocyjna, niezrozumienie idei budżetu partycypacyjnego przez mieszkańców itp.) (tabela 2).

\begin{tabular}{|c|c|c|c|}
\hline \multirow[b]{2}{*}{ Zasady } & \multicolumn{2}{|c|}{ Korzyści z wdrożenia budżetu partycypacyjnego } & \multirow[b]{2}{*}{ Zagrożenia } \\
\hline & $\begin{array}{c}\text { z punktu widzenia } \\
\text { mieszkańców }\end{array}$ & $\begin{array}{c}\text { z punktu widzenia } \\
\text { władz }\end{array}$ & \\
\hline $\begin{array}{l}\text { 1. Wiążący wynik } \\
\text { procedury. } \\
\text { 2. Przejrzystość } \\
\text { i jawność proce- } \\
\text { dury. } \\
\text { 3. Otwartość i inklu- } \\
\text { zyjność procesu. } \\
\text { 4. Zapewnienie de- } \\
\text { baty z udziałem } \\
\text { mieszkańców } \\
\text { 5. Wspieranie } \\
\text { aktywności } \\
\text { mieszkańców } \\
\text { 6. Myślenie długo- } \\
\text { falowe }\end{array}$ & $\begin{array}{l}\text { - możliwość partycy- } \\
\text { pacji w decyzjach } \\
\text { dot. społeczności } \\
\text { lokalnej, } \\
\text { - wzmocnienie } \\
\text { odpowiedzialności } \\
\text { mieszkańców za } \\
\text { dobro wspólne, } \\
\text { - integracja mieszkań- } \\
\text { ców } \\
\text { - wpływ na rozwój } \\
\text { najbliższego miejsce } \\
\text { zamieszkania (dziel- } \\
\text { nicy, osiedla), } \\
\text { - kontrola obywatel- } \\
\text { ska, } \\
\text { - wzrost identyfikacji } \\
\text { z miejscem zamiesz- } \\
\text { kania, } \\
\text { - edukacja na temat } \\
\text { funkcjonowania } \\
\text { samorządu }\end{array}$ & $\begin{array}{l}\text { - umocnienie legitymi- } \\
\text { zacji władzy, } \\
\text { - budowanie zaufania } \\
\text { na linii przedstawi- } \\
\text { ciele władz - } \\
\text { mieszkańcy, } \\
\text { - wzrost efektywności } \\
\text { gospodarowania } \\
\text { środkami publiczny- } \\
\text { mi, } \\
\text { - integracja mieszkań- } \\
\text { ców, } \\
\text { - wzmocnienie postaw } \\
\text { obywatelskich } \\
\text { - wspieranie różno- } \\
\text { rodnych form aktyw- } \\
\text { ności społecznej } \\
\text { - promocja idei dobre- } \\
\text { go rządzenia }\end{array}$ & $\begin{array}{l}\text { - opór władz przed } \\
\text { włączeniem miesz- } \\
\text { kańców w proces } \\
\text { decyzyjny, } \\
\text { - niska świadomość } \\
\text { obywatelska, } \\
\text { - brak wiedzy } \\
\text { i doświadczenia } \\
\text { w zakresie realizacji } \\
\text { budżetu partycypa- } \\
\text { cyjnego, } \\
\text { - kopiowanie niewła- } \\
\text { ściwych rozwiązań, } \\
\text { - zbyt mała licz- } \\
\text { ba urzędników } \\
\text { zaangażowanych } \\
\text { w przygotowa- } \\
\text { nie, prowadzenie } \\
\text { i kontrolę przebie- } \\
\text { gu poszczególnych } \\
\text { etapów budżetu, } \\
\text { - symboliczna pula } \\
\text { środków, } \\
\text { - duże rozdrobnienie } \\
\text { projektów, } \\
\text { - pominięcie etapu } \\
\text { dyskusji z miesz- } \\
\text { kańcami na temat } \\
\text { roli, znaczenia } \\
\text { budżetu partycypa- } \\
\text { cyjnego, } \\
\text { - niewłaściwa kam- } \\
\text { pania informacyjna } \\
\text { i promocyjna }\end{array}$ \\
\hline
\end{tabular}

Tabela 2. Zasady, korzyści i zagrożenia budżetu partycypacyjnego

Źródło: opracowanie własne na podstawie: Standardy procesów budżetu partycypacyjnego w Polsce, Warszawa 2014, s. 6-7; W. Kłębowski, Budżet partycypacyjny. Krótka historia obsługi, Warszawa 2013, <http://www.instytutobywatelski.pl/wpcontent/uploads/2013/03/budzet_par- 
W Polsce idea budżetu partycypacyjnego urzeczywistniła się całkiem niedawno, tj. dopiero w 2011 kiedy to Sopot (jako pierwsze miasto) przystąpił do jego wprowadzenia. Inicjatorem przedsięwzięcia była nieformalna grupa mieszkańców (Sopocka Inicjatywa Rozwojowa), chcąca zdynamizować zrównoważony rozwój miasta m.in. poprzez pobudzenie aktywności obywatelskiej w podejmowaniu decyzji lokalnych ${ }^{17}$. Budżet partycypacyjny stał się szybko popularny również $\mathrm{w}$ innych polskich miastach (według stanu na koniec $2013 \mathrm{r}$. doświadczenia $\mathrm{z}$ budżetem partycypacyjnym miało ponad siedemdziesiąt gmin i miast ${ }^{18}$ ). Jak wskazują D. Kraszewski i M. Mojkowski, złożyło się na to kilka ważnych elementów, a mianowicie ${ }^{19}$ :

- rosnąca aktywność i ambicje mieszkańców,

- traktowanie budżetu partycypacyjnego jako karty przetargowej w wyborach samorządowych,

- społeczne, gospodarcze i polityczne korzyści z punktu widzenia rozwoju jednostki,

- rywalizacja między jednostkami samorządowymi,

- zainteresowanie mediów.

Procedura realizacji budżetu partycypacyjnego w polskich miastach jest podobna, choć trudno mówić o jednym, uniwersalnym jego modelu (jednostka wprowadzająca budżet obywatelski często konstruuje swoje własne reguły, w zależności od swoich potrzeb i możliwości, podpierając się przy tym już istniejącymi przykładami). Można jednak wyodrębnić określony ogólny schemat postępowania zakładający: zgłaszanie projektów przewidzianych do realizacji w ramach budżetu partycypacyjnego, weryfikację przedłożonych projektów, przygotowanie listy projektów objętych głosowaniem, wybór określonej liczby projektów przez mieszkańców i ich realizację. Należy tutaj wskazać ważną kwestię wiążącą się z jego funkcjonowaniem. Budżet partycypacyjny w polskim wydaniu obrazuje „pomysł” zagospodarowania przez mieszkańców części środków budżetu danej jednostki samorządu terytorialnego ${ }^{20}$. Ograniczenie finansowe w jego ramach rodzi konieczność wyboru projektów mających największe znaczenie dla mieszkańców. Dokonuje się

17 E. Stokłuska, Opis przykładu partycypacji. budżet obywatelski w Sopocie, http:// partycypacjaobywatelska.pl/uploads/pdf/praktyka_budzet_obywatelski_sopot.pdf (25.07.2015).

18 D. Kraszewski, M. Mojkowski, Budżet obywatelski w Polsce, Warszawa 2014, s. 4.

19 Ibidem, s. 4-5.

20 W obowiązującym prawie projekt budżetu jest przygotowywany przez organ wykonawczy jednostki samorządu terytorialnego, a przyjmowany przez władze stanowiąco-kontrolne. Wydzielenia kwoty budżetu partycypacyjnego dokonuje się najczęściej w drodze uchwały lub zarządzenia, jako deklaracji że wyniki głosowania będą wiążące. 
tego arbitralną decyzją osób sprawujących władzę pod kątem formalnym (np. poprawności wypełnienia formularza, złożenie go w terminie, zgodności propozycji z regulaminem, możliwości ich realizacji itp.) czy też wykonalności technicznej ${ }^{21}$. Sposób podejmowania rozstrzygnięć w takim zakresie nie budzi jednak większego niezadowolenia i sprzeciwu mieszkańców, choć zdecydowanie lepszą metodą jest budowanie konsensusu społecznego, co pozwala na ograniczenie konfliktów związanych z koniecznością wyboru między alternatywnymi, konkurencyjnymi wobec siebie rozwiązaniami ${ }^{22}$. Nierzadko weryfikacja projektu dotyka również jego merytorycznej strony (np. miejsca realizacji w przestrzeni publicznej, znaczenia społecznego, wartości promocyjnej, atrakcyjności przestrzennej itp.), co wskazuje już na uznaniowość oceny wartości zgłoszonego projektu, dowolność wyboru ${ }^{23}$. To natomiast zakłóca partycypacyjny charakter budżetu.

Analiza dotychczasowych polskich doświadczeń odnośnie do tego rodzaju budżetu wskazuje jednak na szereg niedociągnięć „konstrukcyjnych”. Zdaniem W. Kłębowskiego zasadniczym, najczęściej popełnianym błędem, jest po pierwsze opracowywanie założeń budżetu partycypacyjnego z pominięciem konsultacji z mieszkańcami, po drugie bez uwzględnienia konkretnych lokalnych uwarunkowań ${ }^{24}$. Rzadko organizowane są także spotkania $\mathrm{z}$ właściwymi adresatami budżetu partycypacyjnego tj. mieszkańcami, mające na celu wyjaśnienie istoty i celowości tego rodzaju przedsięwzięć. Widoczna jest również preferencja projektów infrastrukturalnych, nierzadko niewspółgrających z realizowanymi kierunkami rozwoju. Zgłaszane projekty weryfikowane są zazwyczaj odgórnie, a sam budżet jest podatnym gruntem do tworzenia nowych organów decyzyjnych, komórek w strukturach organizacyjnych urzędów czy też organizacji społecznych. Szereg budżetów nie wpisuje się w główne zasady czy też nie odzwierciedla głównej myśli partycypacji społecznej jako takiej, ograniczając pełny udział mieszkańców w realizacji budżetu do wybranych obszarów. Wykluczenie dotyka najczęściej najistotniejszych kwestii związanych z partycypacją mieszkańców, tj. ustalanie zasad budżetu, możliwość współuczestniczenia w weryfikacji projektów, realizacji zgłoszonych projektów czy też odpowiedzialności za sprawy lokalne (tabela 3).

21 D. Kraszewski, M. Mojkowski, op. cit., s. 15.

22 M. Dworakowska, Rola i znaczenie budżetu partycypacyjnego w rozwoju społeczeństwa obywatelskiego, [w:], Oblicza społeczeństwa obywatelskiego. Państwo. Gospodarka. Świat, red. J. Osiński, J.Z. Popławska, Warszawa 2014, s. 64.

23 D. Kraszewski, M. Mojkowski, op. cit., s. 15.

24 W. Kłębowski, Budżet partycypacyjny. Ewaluacja, Warszawa 2014, s. 36-37. 


\begin{tabular}{|c|c|c|}
\hline \multirow[t]{2}{*}{ Cecha } & \multicolumn{2}{|c|}{$\begin{array}{l}\text { Odsetek budżetów } \\
\text { partycypacyjnych (\%) }\end{array}$} \\
\hline & Tak & Nie \\
\hline - w ramach, których odbyły się spotkania mieszkańców & 32,0 & 46,4 \\
\hline - dot. precyzyjnej i wiążącej kwoty środków finansowych & 78,4 & 13,4 \\
\hline $\begin{array}{l}\text { - dot. całego terytorium samorządu (gminy, powiatu, } \\
\text { województwa) }\end{array}$ & 83,5 & 16,5 \\
\hline - mających wiążący charakter & 20,6 & 66,0 \\
\hline - odbywających się cyklicznie (przynajmniej dwie sesje) & 42,3 & (czas pokaże; 55,7 ) \\
\hline $\begin{array}{l}\text { - spełniających podstawowe kryteria wynikające z defini- } \\
\text { cji budżetu partycypacyjnego }\end{array}$ & 9,3 & 90,7 \\
\hline - w których zasady ustalono w sposób partycypacyjny & 4,1 & 73,2 \\
\hline - w których spotkania mieszkańców mają moc decyzyjną & 23,3 & 60,6 \\
\hline - w których wyodrębniono różne skale terytorialne & 13,4 & 32,0 \\
\hline $\begin{array}{l}\text { - w których dozwolone są projekty dot. wszystkich kom- } \\
\text { petencji gminy }\end{array}$ & 69,1 & 24,7 \\
\hline $\begin{array}{l}\text { - w których mieszkańcy mają możliwość współuczestni- } \\
\text { czenia w procesie weryfikacji zgłaszanych projektów }\end{array}$ & 3,1 & 79,4 \\
\hline $\begin{array}{l}\text { - w których mieszkańcy mają możliwość współuczestnic- } \\
\text { twa w procesie realizacji zgłoszonych pomystów }\end{array}$ & 2,1 & 19,6 \\
\hline $\begin{array}{l}\text { - w których mieszkańcy mają możliwość współuczestnic- } \\
\text { twa w procesie ewaluacji budżetu partycypacyjnego }\end{array}$ & 3,1 & 17,5 \\
\hline $\begin{array}{l}\text { - w których mieszkańcy mają możliwość przejęcia więk- } \\
\text { szej odpowiedzialności za swój samorząd }\end{array}$ & - & 91,8 \\
\hline
\end{tabular}

Tabela 3. Cechy charakterystyczne budżetów partycypacyjnych zrealizowanych przez polskie jednostki samorządu terytorialnego

Objaśnienie: (1) Analizą objęto 97 edycji budżetów partycypacyjnych w 72 samorządach, (2) tabela nie ujmuje pozostałych wariantów odpowiedzi jak: raczej tak, raczej nie, czas pokaże, brak danych Źródło: W. Kłębowski, Budżet partycypacyjny. Ewaluacja, Warszawa 2014, s. 14-31.

Przyjęte rozwiązania w zakresie budżetu partycypacyjnego w zasadniczym stopniu determinują jego jakość, jak i stopień upodmiotowienia mieszkańców (sprowadzenie ich jedynie do roli zgłaszających projekty i głosujących, czy też jako partnerów współdecydujących na co wydać wskazane środki finansowe) ${ }^{25}$. Bez względu na jego konstrukcję można go traktować jako narzędzie obywatelskiego rozdysponowania pieniędzy publicznych, przynajmniej z założenia, na najistotniejsze z punktu widzenia zgłaszających przedsięwzięcia (czy partycypacyjne - wydaje się, że pozostaje to $\mathrm{w}$ dalszym ciągu w kręgu dyskusji).

25 B. Mateja, Budżet partycypacyjny w Polsce - wdrożenie i perspektywy, http:// dspace.uni.lodz.pl/xmlui/bitstream/handle/11089/3752/budzet-partycypacyjny-wpolsce-wdrozenie-i-perspektywy.pdf?sequence=1\&isAllowed=y (dostęp 31.07.2015). 


\section{Budżet obywatelski w Łodzi - analiza edycji 2014-2016}

Początki budżetu obywatelskiego w Łodzi sięgają 2012 r., kiedy to środowisko organizacji pozarządowych zwróciło uwagę władz miasta na tego rodzaju formę uczestnictwa mieszkańców $\mathrm{w}$ procesie podejmowania ważnych decyzji dotyczących budżetu. Uznana ona została za kluczowy element partycypacji społecznej i jeden $z$ istotniejszych filarów Strategii Rozwoju Miasta Łodzi 2020+ ${ }^{26}$. Przyjęta przez Radę Miejską w Lodzi uchwała umożliwiła podjęcie przez organ wykonawczy wszelkich niezbędnych prac mających na celu przygotowanie procedur i zasad realizacji budżetu obywatelskiego ${ }^{27}$. Tym samym po raz pierwszy w budżecie wydzielono środki finansowe pozwalające na realizację projektów w ramach wspomnianego budżetu w 2014 r.

Przyjęta procedura budżetu obywatelskiego w latach 2014 i 2015 nie ulegała większym przekształceniom (tabela 4). Pewne zmiany wprowadzono przy III edycji budżetu 2016 w zakresie: kwoty przeznaczonej na poszczególne zadania (kwestia ta zostanie omówiona w dalszej części artykułu), harmonogramu, propozycji zadań, formularza zgłoszeniowego, uzgadniania propozycji, możliwości modyfikowania zadania lokalnego, głosowania na zadania lokalne i realizacji przegłosowanych projektów. Nie przemodelowują one jednak w sposób zasadniczy rozwiązań przyjętych przy I edycji. Warto jednak zwrócić uwagę na fakt iż propozycja zadania może dotyczyć tylko jednej lokalizacji, wraz ze wskazaniem jednostki pomocniczej miasta (osiedla), na którym ma być ono realizowane (dzięki temu mieszkańcy szybciej i łatwiej zorientują się, które projekty dotyczą ich najbliższej okolicy). Wprowadzono również wymóg określenia dostępności zadania dla mieszkańców (np. na temat ewentualnej odpłatności, adresatów zadania). Bieżąca edycja budżetu obywatelskiego (2016) przewiduje także możliwość uzgadniania zgłoszonych propozycji dotyczącego tego samego terenu, budynku, przez samych zgłaszających (przy współudziale pracowników właściwych komórek merytorycznych urzędu, co wynika z trybu weryfikacji projektów) odnośnie do ewentualnego ich połączenia czy też traktowania jako niezależnych. Kolejnym novum jest szansa modyfikacji projektów w sytuacji przekroczenia dozwolonego limitu kosztów w danej grupie zadań (w przypadku braku zgody

26 G. Justyński, Doświadczenia łódzkiego budżetu obywatelskiego, „Kronika Miasta Łodzi" 2013, Nr 4, s. 27.

27 Uchwała Rady Miejskiej w Łodzi Nr XL/759/12 z dnia 16 maja 2012 r. Stanowisko w sprawie potrzeby wprowadzenia procedur i zasad realizacji części budżetu Miasta Łodzi - budżetu obywatelskiego. 
autora, w przypadku zadania lokalnego może ono przejść do puli zadań ogólnomiejskich). W odróżnieniu od dwóch pierwszych edycji budżetu rozszerzeniu uległa procedura weryfikacji zgłoszonych projektów. Po sprawdzeniu ich kompletności i poprawności formularzy, przekazywane są one jak dotychczas przez Biuro ds. Partycypacji społecznej do właściwych merytorycznie komórek organizacyjnych. W ich gestii leży przeprowadzenie analizy merytorycznej i, począwszy od III edycji, przygotowanie rekomendacji dla doraźnej komisji ds. budżetu obywatelskiego, mającej zadecydować, które propozycje zadań zostaną umieszczone na listach do głosowania. Ocena zadań nie przebiega po kątem ich treści. Odrzucenie propozycji może nastąpić jedynie w momencie braku możliwości jej wykonania ze względów formalnych, dłuższego czasu realizacji niż jeden rok bądź przekroczenia maksymalnej kwoty na zadanie ${ }^{28}$. Ingerowanie w zakres propozycji zadań przedłożonych przez mieszkańców, w tym zmiany miejsca realizacji jest możliwe jedynie za zgodą ich autorów.

\begin{tabular}{|l|l|l|l|}
\hline \multirow{2}{*}{ Wyszczególnienie } & \multicolumn{3}{|c|}{ Edycja budżetu obywatelskiego } \\
\cline { 2 - 4 } \multicolumn{1}{c|}{1} & \multicolumn{1}{|c|}{ I 2014 } & \multicolumn{1}{|c|}{ II 2015} & \multicolumn{1}{c|}{ III 2016 } \\
\hline $\begin{array}{l}\text { Kto może zgłaszać } \\
\text { projekty }\end{array}$ & $\begin{array}{l}\text { Każdy mieszkaniec } \\
\text { miasta }\end{array}$ & $\begin{array}{l}\text { Każdy mieszkaniec } \\
\text { miasta }\end{array}$ & $\begin{array}{l}\text { Każdy mieszkaniec } \\
\text { miasta }\end{array}$ \\
\hline $\begin{array}{l}\text { Wymóg popar- } \\
\text { cia zgłaszanego } \\
\text { projektu }\end{array}$ & Tak (15 osób) & Tak (15 osób) & Tak (15 osób) \\
\hline $\begin{array}{l}\text { Przeznaczenie } \\
\text { środków }\end{array}$ & $\begin{array}{l}\text { Projekty inwestycyjne } \\
\text { i „miękkie” w ramach } \\
\text { zadań znajdujących się } \\
\text { w kompetencji gminy } \\
\text { i powiatu }\end{array}$ & $\begin{array}{l}\text { Projekty inwestycyjne } \\
\text { i „miękkie” w ramach } \\
\text { zadań znajdujących się } \\
\text { w kompetencji gminy } \\
\text { i powiatu }\end{array}$ & $\begin{array}{l}\text { Projekty inwestycyjne } \\
\text { i „miękkie” w ramach } \\
\text { zadań znajdujących się } \\
\text { w kompetencji gminy } \\
\text { i powiatu }\end{array}$ \\
\hline Podział zadań & $\begin{array}{l}\text { Zadania lokalne } \\
\text { i ogólnomiejskie }\end{array}$ & $\begin{array}{l}\text { Zadania lokalne } \\
\text { i ogólnomiejskie }\end{array}$ & $\begin{array}{l}\text { Zadania lokalne } \\
\text { i ogólnomiejskie }\end{array}$ \\
\hline $\begin{array}{l}\text { Weryfikacja pro- } \\
\text { jektów }\end{array}$ & $\begin{array}{l}\text { Pod względem po- } \\
\text { prawności i komplet- } \\
\text { ności wniosku, zgod- } \\
\text { ności z prawem oraz } \\
\text { możliwości realizacji } \\
\text { w ciągu roku }\end{array}$ & $\begin{array}{l}\text { Pod względem po- } \\
\text { prawności i komplet- } \\
\text { ności wniosku, zgod- } \\
\text { ności z prawem oraz } \\
\text { możliwości realizacji } \\
\text { w ciągu roku }\end{array}$ & $\begin{array}{l}\text { Pod względem po- } \\
\text { prawności i komplet- } \\
\text { ności wniosku, zgod- } \\
\text { ności z prawem oraz } \\
\text { możliwości realizacji } \\
\text { w ciągu roku }\end{array}$ \\
\hline $\begin{array}{l}\text { Osoby uprawnione } \\
\text { do głosowania }\end{array}$ & $\begin{array}{l}\text { Mieszkańcy, którzy } \\
\text { ukończyli 16 lat (nie } \\
\text { jest wymagane zamel- } \\
\text { dowanie) }\end{array}$ & $\begin{array}{l}\text { Mieszkańcy, którzy } \\
\text { ukończyli 16 lat (nie } \\
\text { jest wymagane zamel- } \\
\text { dowanie) }\end{array}$ & $\begin{array}{l}\text { Mieszkańcy, którzy } \\
\text { ukończyli 16 lat (nie } \\
\text { jest wymagane zamel- } \\
\text { dowanie) }\end{array}$ \\
\hline
\end{tabular}

28 Budżet obywatelski III edycja. Materiały informacyjne, http://budzet.dlalodzi. info/wp-content/uploads/2013/03/folder_internet.pdf (dostęp 31.07.2015). 


\begin{tabular}{|l|l|l|l|}
\hline \multicolumn{1}{|c|}{1} & \multicolumn{1}{|c|}{2} & \multicolumn{1}{c|}{3} & \multicolumn{1}{c|}{4} \\
\hline $\begin{array}{l}\text { Sposoby głoso- } \\
\text { wania }\end{array}$ & $\begin{array}{l}\text { Internet, osobiście } \\
\text { w punktach wyborczych, } \\
\text { korespondencyjnie }\end{array}$ & $\begin{array}{l}\text { Internet, osobiście } \\
\text { w punktach wyborczych, } \\
\text { korespondencyjnie }\end{array}$ & $\begin{array}{l}\text { Internet, osobiście } \\
\text { w punktach wyborczych, } \\
\text { korespondencyjnie }\end{array}$ \\
\hline $\begin{array}{l}\text { Informacja na } \\
\text { tematy negatyw- } \\
\text { nie i pozytywnie } \\
\text { zweryfikowanych } \\
\text { wniosków }\end{array}$ & Tak & Tak & Tak \\
\hline $\begin{array}{l}\text { Działania informa- } \\
\text { cyjno-edukacyjne }\end{array}$ & Tak & Tak & Tak \\
\hline
\end{tabular}

Tabela 4. Cechy budżetu obywatelskiego w Łodzi poszczególnych edycji Objaśnienie:

- projekty miękkie - wsparcie wydarzeń i projektów kulturalnych, edukacyjnych, artystycznych, - zadania lokalne - odpowiadające potrzebom mieszkańców jednego z wydzielonych obszarów, zlokalizowane w tych obszarach albo skierowane do mieszkańców zamieszkujących wydzielone obszary (w przypadku łodzi obszary te pokrywają się z granicami dawnych 5 dzielnic tj. Bałut, Górnej, Polesia, Śródmieścia i Widzewa), - zadania ogólnomiejskie - dotyczące potrzeb mieszkańców więcej niż jednego wydzielonego obszaru miasta, lub miejsce ich realizacji nie jest przypisane do jednego wydzielonego obszaru miasta.

Źródło: opracowanie własne na podstawie: Materiały informacyjne Urzędu Miasta Łodzi dot. poszczególnych edycji budżetu obywatelskiego, Zarządzenie Prezydenta Miasta Łodzi nr 5837/ $\mathrm{VI} / 14$ z dnia 5 marca 2014 r. w sprawie przeprowadzenia konsultacji społecznych dotyczących budżetu obywatelskiego na 2015 r.

Sednem budżetu obywatelskiego jest jednak jego wielkość pozwalająca (bądź też nie) na podjęcie decyzji odnoście istotnych (a nie symbolicznych) z punktu widzenia mieszkańców przedsięwzięć. W Łodzi, jak do tej pory, wyodrębniono największy budżet obywatelski spośród wszystkich miast. W I edycji miasto na ten cel przeznaczyło $20 \mathrm{mln} \mathrm{zł}$, w kolejnych już $40 \mathrm{mln} \mathrm{zl}$, co stanowi 1 proc. dochodów budżetu ogółem i 3 proc. wydatków majątkowych (tabela 5).

\begin{tabular}{|c|c|c|c|}
\hline \multirow{2}{*}{ Wyszczególnienie } & \multicolumn{3}{|c|}{ Edycja budżetu obywatelskiego } \\
\hline & I 2014 & II 2015 & III 2016 \\
\hline $\begin{array}{l}\text { Kwota ogółem } \\
\text { z. lokalne } \\
\text { z. ogólnomiejskie }\end{array}$ & $\begin{array}{l}20 \mathrm{mln} \text { zł } \\
15 \mathrm{mln} \text { zł } \\
\text { (3 mln na każdy } \\
\text { obszar) } \\
5 \mathrm{mln} \text { zt }\end{array}$ & $\begin{array}{l}40 \mathrm{mln} \text { zt } \\
30 \mathrm{mln} \\
(6 \mathrm{mln} \text { na każdy } \\
\text { obszar) } \\
10 \mathrm{mln}\end{array}$ & $\begin{array}{l}40 \mathrm{mln} \text { zł } \\
30 \mathrm{mln} \\
(6 \mathrm{mln} \text { na każdy } \\
\text { obszar) } \\
10 \mathrm{mln}\end{array}$ \\
\hline $\begin{array}{l}\text { Liczba projektów: } \\
\text { zgłoszonych } \\
\text { zakwalifikowanych } \\
\text { realizowanych }\end{array}$ & $\begin{array}{l}908 \\
759 \\
47\end{array}$ & $\begin{array}{l}871 \\
751 \\
65\end{array}$ & $\begin{array}{l}645 \\
- \\
-\end{array}$ \\
\hline
\end{tabular}

Tabela 5. Budżet obywatelski w Łodzi - kwoty oraz liczba projektów Źródło: opracowanie własne na podstawie materiałów informacyjnych nt. budżetu obywatelskiego Urzędu miasta Łodzi, http://uml.lodz.pl/budzet_obywatelski/ (dostęp 1.08.2015). 
W bieżącej edycji zdecydowano się na ograniczenie wartości projektów, mając na uwadze zwiększenie ilości tych wybranych i następnie wprowadzonych do wykonania. Stąd też kwota przeznaczona na poszczególne zadania nie może przekroczyć 25 proc. całkowitej kwoty na zadania lokalne czy ogólnomiejskie. W praktyce oznacza to, że kalkulacja projektu lokalnego nie może przekraczać 1,5 mln zł, a ogólnomiejskiego - 2,5 mln zł. W minionych edycjach minimalna wartość wybranego do realizacji projektu w 2014 r. wyniosła 5 tys. zł maksymalna zaś ponad 3 mln zł. W 2015 r. - analogicznie 1 tys. zł i 4,2 mln zł (tabela 6).

\begin{tabular}{|c|c|c|}
\hline Rok & Kwota w zt & Projekt \\
\hline \multicolumn{3}{|r|}{2014} \\
\hline \multirow[t]{6}{*}{$\min }$. & 5000 & zainstalowanie progu zwalniającego \\
\hline & 6000 & trener /instruktor sportów plażowych \\
\hline & 1200000 & modernizacja i rozbudowa budynku i bazy sportowej szkoły podstawowej \\
\hline & 1300000 & Otwarte wielofunkcyjne boiska dla mieszkańców \\
\hline & 1400000 & Przekształcenie ulicy w tzw. woonerf \\
\hline & 1750000 & Wymiana nawierzchni asfaltowej \\
\hline $\max$. & 3117000 & Łódzki rower miejski* \\
\hline \multicolumn{3}{|r|}{2015} \\
\hline \multirow[t]{11}{*}{ Min. } & 1000 & przystanek \\
\hline & 2000 & zakup i montaż lustra drogowego \\
\hline & 3000 & Odnowienie zabytkowego kamienia \\
\hline & 1000000 & $\begin{array}{l}\text { Ogród dachowy, taras widokowy, kawiarnia - przygotowanie projektu } \\
\text { remontu i przebudowy budynków pofabrycznych, uwzględniającego } \\
\text { wykonanie „zielonych dachów” }\end{array}$ \\
\hline & 1120000 & Free WiFi in Łódź - bezpłatny miejski Internet w autobusach i tramwajach \\
\hline & 1234000 & Ogólnodostępne boisko wielofunkcyjne przy gimnazjum publicznym \\
\hline & 1343000 & $\begin{array}{l}\text { Stworzenie nowoczesnej bazy edukacyjnej oraz budowa całorocznego } \\
\text { kortu tenisowego przy szkole podstawowej }\end{array}$ \\
\hline & 2200000 & Przekształcenie ulicy w tzw. woonerf \\
\hline & 2250000 & Przekształcenie ulicy w tzw. woonerf \\
\hline & 2325000 & Utworzenie parku - ogrodów Jana Karskiego \\
\hline & 3700000 & Przebudowa ulicy \\
\hline Max. & 4200000 & $\begin{array}{l}\text { Wymiana nawierzchni chodników na kostkę brukową oraz nawierzchni } \\
\text { miejsc postojowych na kostkę betonową }\end{array}$ \\
\hline
\end{tabular}

Tabela 6. Minimalne i maksymalne kwoty realizowanych projektów ze środków budżetu obywatelskiego w 2014 i 2015 r.

* projekt nie został zrealizowany Źródło: opracowanie własne na podstawie: Uchwała rady Miejskiej w Łodzi Nr LXXIX/1646/14 z dnia 16 stycznia 2014 r. w sprawie uchwalenia budżetu miasta Łodzi na 2014 r.; Uchwała Rady Miejskiej w Łodzi Nr IV/50/15 z dnia 14 stycznia 2015 r. w sprawie uchwalenia budżetu miasta Łodzi na 2015 r. 
Analiza projektów przyjętych do realizacji wskazuje na ich różnorodność i jednocześnie ukierunkowanie. Są to bowiem projekty „twarde” dotyczące rozbudowy i modernizacji infrastruktury drogowej, sportowej, rekreacyjno-wypoczynkowej oraz „miękkie” adresowane do poszczególnych grup mieszkańców jak np. uruchomienie Osiedlowych Banków Czasu dla mieszkańców, programy edukacyjno-artystyczne dla dzieci i młodzieży dotkniętych wykluczeniem społecznym czy nieodpłatne pozyskiwanie, gromadzenie i przekazywanie żywności najuboższym. Ze środków budżetu obywatelskiego dokonywane są różnego rodzaju zakupy mające najczęściej służyć wybranym, często wąskim grupom mieszkańców, takie jak np. sprzęt sportowy, książki i audiobooki, komputery, programy komputerowe, sprzęt fotograficzny czy pianino. W ogólnej kwocie środków budżetu nie stanowiły one więcej niż 3 proc..$^{29}$ Ocena ich wagi dokonywana jest raczej pod kątem jakościowym - przeznaczenia, trwałości, zastosowania, znaczenia dla lokalnej społeczności itp. (w ramach I edycji budżetu obywatelskiego kwota przeznaczona na zakupy kształtowała się w granicach 1,5 proc. podobnie jak na projekty „miękkie”). Zasadnicza część środków ukierunkowana jest jednak na projekty „twarde”, infrastrukturalne obejmujące: budowę, rozbudowę, przebudowę, modernizację, termomodernizację obiektów o różnym przeznaczeniu. Na te cele przeznaczono ok. 85 proc. kwoty budżetu w 2015 r. i praktycznie 90 proc. w 2014 r.

\section{Dyskusja}

Spojrzenie na budżet partycypacyjny (obywatelski), zarówno od strony teoretycznej jak i praktycznej pozwala stwierdzić, iż jest on niewątpliwie przejawem dobrowolnej i świadomej partycypacji społecznej mieszkańców. Ponadto, pełni on funkcję: (1) płaszczyzny budowania więzi i porozumienia pomiędzy mieszkańcami a władzami, (2) bodźca do zmiany mentalności władz w obszarze percepcji sprawowania władzy i mieszkańców jako członków określonej społeczności. Budżet obywatelski może zatem jawić się jako forma dojrzałego dialogu stron zaangażowanych w proces zarządzania publicznego, narzędzie sprzyjające wzrostowi efek-

29 Podziału realizowanych projektów w ramach analizowanych budżetów obywatelskich dokonano w sposób subiektywny. obok kategorii zakupy wyróżniono: projekty „twarde” - budowa, rozbudowa, modernizacja obiektów o różnym przeznaczeniu, „miękkie” - wszelkiego rodzaju działania edukacyjne, kulturalne, artystyczne oraz inne obejmujące np. zatrudnienie rehabilitanta, leczenie zwierząt w zoo, organizację opieki paliatywnej, rehabilitację seniorów itp. 
tywności, przejrzystości wydatkowania środków publicznych. Narzędzie niosące szereg innych wymiernych korzyści dla władz i samych mieszkańców mogących decydować o sprawach dla nich ważnych. Wzbudza on jednak, mimo rosnącej popularności, dyskusje, nasuwa szereg pytań, m.in. o to, czy jako społeczeństwo jesteśmy przygotowani by korzystać $\mathrm{w}$ sposób właściwy $\mathrm{z}$ tego rodzaju narzędzia partycypacji? Czy budżet obywatelski nie jest jedynie wymuszonym gestem władz w stosunku do mieszkańców, metodą przyciągania potencjalnych wyborców. I w końcu jaka jest przyszłość budżetu obywatelskiego w warunkach pogłębiających się problemów finansowych polskich samorządów?.

Postawione pytania są bardzo złożone, uwarunkowane wieloma czynnikami. Trudno zatem wskazać jednoznaczną na nie odpowiedź, już choćby z faktu, że sam budżet obywatelski jest zagadnieniem niedoprecyzowanym w polskiej rzeczywistości. Brak jest jednolitych standardów określających kryteria budżetu czy też wymogi prawne. Punktem wyjścia do jego uruchomienia jest uprawnienie organów stanowiących jednostek samorządu terytorialnego do podjęcia konsultacji z mieszkańcami ${ }^{30}$. Oparcie budżetu obywatelskiego tylko na tej przesłance może naruszyć zasadę wiążącego wyniku, co natomiast zaprzecza jego idei i może doprowadzić do zniechęcenia mieszkańców omawianą inicjatywą i utratą zaufania do władz.

Budżet obywatelski w swoim założeniu to nie jest jedynie głosowanie nad określonymi projektami. Jego mechanizm zorientowany jest na promowanie inicjatywy, zaangażowania, odpowiedzialności mieszkańców, wspólnego działania na rzecz interesu publicznego, dyskusji a także konsensusu (w najdojrzalszych formach budżetu obywatelskiego). Analiza dotychczasowych edycji budżetu obywatelskiego w Łodzi nie pozwala jednak na potwierdzenie w pełni tego stanowiska. Po pierwsze, spada zainteresowanie budżetem, na co wskazuje zmniejszająca się liczba zgłoszonych przez mieszkańców projektów (do III edycji budżetu zgłoszono, w porównaniu z tą z 2014 r. o 263 zadania mniej). Po drugie, zauważalne są tendencje do organizowania głosów na konkretne zadania, które dotyczą stosunkowo wąskich grup odbiorców, a także pozwalają rozwiązać (niejednokrotnie) bieżące problemy określonych instytucji. Można tutaj wymienić doposażenie w sprzęt medyczny przychodni, wdrożenie elektronicznej dokumentacji w jednym z zakładów opieki zdrowotnej, ochronę danych i sprzętu medycznego poprzez montaż systemu kontroli dostępu do pomieszczeń jednej z miejskich przychodni, zakup komputerów dla określonej biblioteki miejskiej czy zakup gleukometrów, ciśnieniomierza i środków higieny osobistej dla podopiecznych Fundacji Brata

30 A. Kuriata, Budżet partycypacyjny jako przejaw demokracji uczestniczq̨cej w samorzqdzie lokalnym, [w:] Województwo - region - regionalizacja. 15 lat po reformie terytorialnej i administracyjnej, red. J. Korczak, Wrocław 2013, s. 43. 
Alberta. Silny lobbing czyni je w wielu przypadkach bezkonkurencyjnymi wobec innych propozycji. W tym kontekście pojawiają się kolejne pytania: na ile tego rodzaju projekty służą ogółowi mieszkańców danego obszaru, z którego zostały zgłoszone i czy w ogóle mają służyć? W jakim stopniu wpisują się one w przyjęte kierunki rozwoju miasta? A jeśli się nie wpisują, to czy powinny być realizowane w myśl zasady efektywnego wydatkowania środków publicznych, których odbiorcami są przecież wszyscy mieszkańcy. Nasuwa to potrzebę spojrzenia na zagadnienie podziału na zadania lokalne i ogólnomiejskie. Budżet obywatelski jest procesem obarczonym ryzykiem np. niepowodzenia wywołanego brakiem zainteresowania mieszkańców, ale także pojawienia się dysproporcji pomiędzy wyodrębnionymi obszarami w liczbie zgłaszanych i realizowanych zadań lokalnych. Mechanizmem niwelującym to ryzyko jest przyjęty równy podział pieniędzy przeznaczonych na zadania lokalne w ramach wyodrębnianych części miasta (dzielnic, osiedli lub innych w zależności od przyjętych kryteriów). Z drugiej jednak strony, patrząc na przykład Łodzi, obszary głosowania na zadania lokalne nie są jednakowe terytorialnie, stąd postulat wysuwany przez mieszkańców wprowadzenia proporcjonalnego do wielkości wydzielonego obszaru podziału środków. Co może w większym stopniu niż dotychczas sprzyjać wspomnianej dysproporcji. W opinii mieszkańców powinna zatem istnieć możliwość głosowania na projekty lokalne ze wszystkich dzielnic, to zaś stawia pytanie o zasadność podziału na odrębne kategorie zadań - lokalnych i ogólonomiejskich ${ }^{31}$.

Na problem należy spojrzeć nie tylko od strony proceduralnej. Nierównomiernemu wzrostowi jakości życia mieszkańców poszczególnych części miasta (przyjmując, że zadania lokalne mają temu służyć) sprzyja zróżnicowana ich aktywność, jak i aktywność organizacji społecznych, jednostek pomocniczych funkcjonujących na ich terenie, a także wprowadzona możliwość głosowania na zadania $\mathrm{z}$ jednego, dowolnie wybranego rejonu, nienależnie od miejsca zamieszkania (spowodowane to było zapewne chęcią wzmocnienia poczucia wpływu mieszkańców na pozostałe obszary miasta, obok głosowania na zadania ogólnomiejskie).

Niezmiernie ważną kwestią wokół której toczą się liczne polemiki jest skala budżetu obywatelskiego. W większości przypadków nie przekraczają one 1 proc. dochodów jednostki. Jak wskazywano, zasadnicza ich część ukierunkowana jest na różnego rodzaju działania inwestycyjne ale także remontowe. Szczególnie te ostatnie (podobnie jak zakupy) mogą budzić kontrowersje, jako te, o które powinno dbać samo miasto. Istotą budżetu obywatelskiego powinno być przede wszystkim tworzenie nowych obiektów infrastruktury technicznej i społecznej czy też projek-

31 Podsumowanie wyników ankiety ewaluacyjnej II edycji budżetu obywatelskiego w Łodzi na 2015 r., Urząd Miasta Łodzi, Łódź 2014. 
tów edukacyjno-wychowawczych, bezpośrednio na rzecz mieszkańców. W tym kontekście należy zastanowić się nad przełożeniem na potrzeby mieszkańców, choćby danej dzielnicy, np. zakupu pianina, odnowy zabytkowego pianina, remontu toalet w publicznym gimnazjum, poczekalni w przychodni miejskiej, zakupu sprzętu medycznego czy niemedycznego dla poradni czy wdrożenia elektronicznej dokumentacji medycznej. Czy zatem kategorie zadań możliwych do realizacji w ramach środków budżetu obywatelskiego nie powinny być dokładnie sprecyzowane? Można odnieść wrażenie, że finansowanie projektów w ramach zadań znajdujących się w kompetencji danej jednostki samorządu terytorialnego, jak ma to miejsce chociażby w Łodzi, otwiera „furtkę" wszystkim możliwym przejawom inwencji remontowej, modernizacyjnej i zakupowej, głównie jednostek organizacyjnych miasta.

Powyższe rozważania nie wyczerpały całości problematyki, nie wyartykułowano również wszystkich pytań i wątpliwości związanych z budżetem obywatelskim. Autorka wyraża jednak pogląd, że budżet obywatelski jest jednym z bardziej efektywnych mechanizmów zapewniających mieszkańcom trwały wpływ na rozwój miasta, nawet w ramach niewielkiej części budżetu. Wymaga to jednak odejścia od traktowania budżetu w kategorii „lekarstwa na problemy miasta” czy też konkursu projektów zorganizowanego przez jego władze. Jego powodzenie zależy od postaw obywatelskich mieszkańców. Ich kształtowanie wymaga natomiast czasu, chęci i aktywnego zaangażowania władz w życie społeczności lokalnej. Bez tego będzie to tylko narzędzie pozornej partycypacji.

\section{Bibliografia}

Baiocchi G., Participation, Activism, and Politics: The Porto Alegre Experiment, [w:] Depending Democracy. Institutional Innovations in Empowered Participatory Governance, red. Fung A., Wright E.O., London 2003.

Budżet obywatelski III edycja. Materiaty informacyjne, http://budzet. dlalodzi.info/wp-content/uploads/2013/03/folder_internet.pdf (dostęp 31.07.2015).

Budżet partycypacyjny. Jak mieszkańcy moga wspótdecydować o budżecie miasta, Warszawa.
Dworakowska M., Rola i znaczenie budżetu partycypacyjnego w rozwoju społeczeństwa obywatelskiego, [w:] Oblicza społeczeństwa obywatelskiego. Państwo. Gospodarka. Świat, red. Osiński J., Popławska J.Z., Warszawa 2014.

Harkins C., Egan J., The Role of Participatory Budgeting in Promoting Localism and Mobilising Community Assets, Glasgow 2012.

Justyński G., Doświadczenia łódzkiego budżetu obywatelskiego, „Kronika Miasta Łodzi” 2013, Nr 4. 
Kalisiak-Mędelska M., Partycypacja społeczna - przymus czy rzeczywista potrzeba?, „Prace Naukowe Uniwersytetu Ekonomicznego we Wrocławiu” 2011, Nr 241.

Kalisiak-Mędelska M., Partycypacja społeczna na poziomie lokalnym jako wymiar decentralizacji administracji publicznej w Polsce, Łódź 2015.

Kłębowski W., Budżet partycypacyjny. Krótka historia obsługi., Instytut Obywatelski, Warszawa http://www. instytutobywatelski.pl/wpcontent/ uploads/2013/03/budzet_partycypacyjny.pdf (dostęp )

Kłębowski W., Budżet partycypacyjny. Ewaluacja, Warszawa 2014.

Koncepcja Good Governance. Refleksje do dyskusji, Warszawa 2008.

Kraszewski D., Mojkowski M., Budżet obywatelski w Polsce, Warszawa 2014.

Kuriata A., Budżet partycypacyjny jako przejaw demokracji uczestniczacej w samorządzie lokalny, [w:] Województwo - region - regionalizacja. 15 lat po reformie terytorialnej i administracyjnej, red. Korczak J., Wrocław 2013.

Mateja B., Budżet partycypacyjny w Polsce - wdrożenie i perspektywy, http:// dspace.uni.lodz.pl/xmlui/bitstream/ handle/11089/3752/budzet-partycy pacyjny-w-polsce-wdro-zenie-i-perspektywy.pdf?sequence=1\&isAllowed=y (dostęp 31.07.2015).

Materiały informacyjne nt. budżetu obywatelskiego Urzędu miasta Łodzi, http://uml.lodz.pl/budzet_obywatelski/ (dostęp 1.08.2015).

Participatory Budgeting in New York City. 2012-2013 Rulebook, www.participatorybudgeting.org/wp-content/uploads/2012/07/Rulebook.pdf (dostęp 12.07.2015).

Podsumowanie wyników ankiety ewaluacyjnej II edycji budżetu obywatelskiego w Łodzi na 2015 r., Łódź 2014.

Poznański budżet obywatelski - analiza i rekomendacje, „Raport Stowarzyszenia Ulepsz Poznań” 2014, Nr 1.
Rytel-Warzocha A., Partycypacja społeczna w sprawach budżetowych. Model Porto Alegre jako pierwowzór rozwiqzań europejskich, „Przegląd Prawa Konstytucyjnego" 2010, Nr 1.

Rytel-Warzocha A., Budżet obywatelski jako nowa forma społecznej partycypacji, „Przegląd Naukowy Disputatio" 2013, Tom XV.

Sadura P., Podzielmy się kulturą. Budżet partycypacyjny w Domu Kultury Śródmieście. Opis procesu wraz z rekomendacjami, Warszawa 2013.

Sintomer Y., Herzberg C., Röcke A., Participatory Budgeting in Europe: Potentials and Challenges, „International Journal of Urban and Regional Research" 2008, Vol. 32.

Sintomer Y., Herzberg C., Rocke A., Allegretti G., Transnational Models of Citizen Participation: The Case of Participatory Budgeting, „Journal of Public Deliberation" 2012, Vol. 8: Iss. 2.

Standardy procesów budżetu partycypacyjnego w Polsce, Warszawa 2014.

Stokłuska E., Opis przykładu partycypacji. budżet obywatelski w Sopocie, http:// partycypacjaobywatelska.pl/uploads/pdf/praktyka_budzet_obywatelski_sopot.pdf (dostęp 25.07.2015).

Szaranowicz-Kusz M., Budżet partycypacyjny. Jak mieszkańcy moga wspótdecydować o budżecie miasta, Warszawa 2014.

Turnhout E., Van Bommel S., Aarts N., How Participation Creates Citizens: Participatory Governance as Performative Practice, „Ecology and Society" 2010, No. 15(4):26, http://www. ecologyandsociety.org/vol15/iss4/ art26/ (dostęp: 10.03.2014).

Uchwała Rady Miejskiej w Łodzi NrIV/50/15 $z$ dnia 14 stycznia 2015 r. w sprawie uchwalenia budżetu miasta Łodzi na $2015 r$.

Uchwała Rady Miejskiej w Łodzi Nr LXXIX/ 1646/14 z dnia 16 stycznia 2014 r. w sprawie uchwalenia budżetu miasta Łodzi na 2014 r. 
Uchwała Rady Miejskiej w Łodzi Nr XL/759 /12 z dnia 16 maja 2012 r. stanowisko w sprawie potrzeby wprowadzenia procedur i zasad realizacji części budżetu Miasta Łodzi - budżetu obywatelskiego.

Wampler B., A Guide to Participatory Budgeting, [w:] Participatory Budgeting, The World Bank, Public Sector Governance and Accountability Series.
Wojciechowski E., Podgórniak-Krzykacz A., Kalisiak-Mędelska M., Chądzyński J., Władza lokalna a państwo, społeczeństwo irynek. Wspótpraca i konkurencja, Łódź 2014.

Zarzq̨dzenie Prezydenta Miasta Łodzi nr 5837/VI/14 z dnia 5 marca 2014 r. w sprawie przeprowadzenia konsultacji spotecznych dotyczących budżetu obywatelskiego na 2015 r. 